U.S. DEPARTMEIT OF HEALTH, EDUCATIOH, ARD MELFARE NATIONAL INSTITUTE FOR OCCUPATIOLAAL SAFETY AND HEAL CIRICIMNATI, OHIO 45202

HEALTH HAZARD EVALUATION DETERMINATTISY REPCRT NO. 73-73-143

INLAHD MANUFACTURING COH

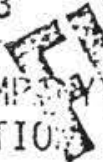

DAYTOH, OHIO

OCTOBER 1974

I. TOXICITY DETERMINATION

It has been determined that exposure to dusts containing small

- amounts of silica (combustion products of coal) is not toxic at the concentrations measured during the clean-up operations in Building $7-A$, Piant 1 , Department 14 , Eoiler Room. This determination is based upon environmental measurenents in the workplace and emplayee intervievs. During the environnental evaluation (February

14, 1974)no significant symptoms were reported by intervieved employees and dust levels were well below those believed to be toxic.

II. DISTRJBUTIOH AND FVAILABILITY OF DETEPIIIMATION REPORT

Copies of this determination report are available upon request from the Hazard Evaluation Services Branch (HIOSH), U.S. Post Office Buildirig, Room 508, 5 th and Walnut Streets, Cincinrati, Ohio 45202. Copies have been sent to:

(a) Inland Manufacturing Division of General Hotors Corporation, Dayton, Ohio.

(b) Authorized Representative of Employees

(c) U.S. Department of Lobor - Region V

(d) NIOSH - Region V

For the purpose of informing the approximately 10 "affected employees" the employer will promptly "post" the Determination Report in a prominent place(s) near where exposed employees vork for a period of 30 calendar days.

III. IITTRODUCTION .

Section 20(a)(6) of the Occupational Safety and Health Act of 1970 , 29 U.S.C. 669 (a)(6), authorizes the Secretary of Health, Education, and lielfare, following a written request by any employer or authorized represeritative of cinployess, to determine whether any substances nomblly folind in the place of emplojment has potentielly toxic effects in such coricentrations as used or found:

The Hational. Institute for Occupatienal Safety and Health received a request fron an authorized representative of employces regarding 
Page 2 - Health Mazard Evaluation Determination 73-73

exposures to coal dust and fly ash during the clean-up operation of

- the boilers, located in Building 1-A, Plant 1, Department 14, at the Inland Manufacturing Division of General Motors Corporation, Dayton, Ohio.

\section{MEALTH HAZARD EVALUATION}

\section{A. Description of Process}

Coal is the fuel used in one or a conbination of three boilers which supply heat and poiver to Inland Manufacturing Company in Dayton, Ohio. The operation of blowing the boiler tubes in the boilers lasts approximately 45 minutes in an-eight-hour shift. One boiler is cleaned every shift This requires two operaiors. The operation consists of 1) blowing the ashes inside the boiler with an air lance to the opposite side of the boiler, 2) shoveling ashes from the interior of the boiler onto a high velocity transoort exhaust system located beloy the floor level, 3) blowing ashes from the combustible chamber inside the boiler, and 4) meclianically removing the ashes from the boiler heat transfer surfaces (heat exchangers).

\section{- B. Evaluation Design/Methods}

An initial observation survey of the Boiler House Building 1-A, Plant 1, Department 14 l:as made on Octoher 14,1973 to assess the alleged hazard. The alleged health hazard in the Boijer House was coal dust and f7y ash exposure during the boiler clean-up operation. During the initial visit the boiler clean-up operation had been performed carlier in the shift. Therefore the environmental evaluation on this occasion was rather limited.

On February 14, 1974 follow-up survey was made. Environmental samples vere obtained curing the clean-up operation. A total of five filter samples were collected in the area, two personal for total dust and respirable fraction and three general area samples for total dust and Si02. The air samples were analyzed by NIOSH's Cincinnati laboratories?

\section{Evaluation Criteria}

The occupational health standards promulgated by the U.S. Department of Labor (Federal Register, October 1972, Title 29, Chapter XVII, Subpart G, Table G-3). 
Page 3 - Health Hazard Evaluation Determination 73-73-

\section{Substances}

Total Dust (nuisance)

Respirable Dust (nuisance)

Quartz (Respirable Fraction)

Quartz (Total Dust) 8-Hour-Time-ligighted
Average $\mathrm{mg} / \mathrm{m}^{3 *}$

Coal Dust (respirable Fraction .

less than $5 \% \mathrm{SiO}_{2}$ )

$15 \mathrm{mg} / \mathrm{M}^{3}$

$5 \mathrm{mg} / 1 \mathrm{~s} 3$

$10 \mathrm{mg} / \mathrm{H}^{3}$

$\%$ Resp $\mathrm{SiO}_{2}+2$

$30 \mathrm{mg} / \mathrm{m}^{3}$

$\% \mathrm{SiO}_{2}+2$

\section{$2.4 \mathrm{mg} 7 \mathrm{~m}^{3}$}

* Milligrams of particulate per cubic meter of air. Occupational Health stanciaids for individual substances are established at levels designed to proiect workers. occupationally exposed on an 8-hour per day, 40 hours per weak basis over a normal working life time.

D. Evaluation Results and Discussions

\section{Environmental}

Five samples vere collected for total dust and respirable fraction. during the clean-up operation. The airborne dust concentrations were very low. Hence, a silica $\left(\mathrm{SiO}_{2}\right)$ determination was noi made. However, a $\mathrm{SiO}_{2}$ cleterniination was macie on a bulk sample and $2.2 \%$ free silica was found. A dust standard of $2.4 \mathrm{mg} / \mathrm{it3}$ was determined using the percent (2.2\%) of free silica found in the bulk sample. Since all total dust levels were less than $0.78 \mathrm{mq} / 11^{3}$ it has been determined that the sine level is insignificant.

The dust concentration leve is obtained on the filters were well below the established Federal Standards of $15 \mathrm{mg} / \mathrm{M}^{3}$ for total dust (nuisance).

\section{Hedical}

Five of the ten employees were interviel:ed during the first and second shift in regard to health problens which might be associated with their vork environnient. An analy'sis of the medical questionnaire responses indicated that one employee complained of increased sinus problemis attributed to dust during the clean-up operation. No other problems were attributed to the work enviroinent. 
Page 4 - llealth Hazard Evaluation Determination 73-73-

v. AUTHORSHIP ANID ACKNO:LLEDGMENTS

Report Prepared By: Rayiriond L. Ruhe

Industrial Hygienist

Hazard Evaluation Services Brarich

Cincinnati, Ohio

Originating Office:

Jerome P. Flesch, Chief

Hazard Evaluation Services Branch

Cincinnati, Ohio

Acknowledgments

Environmental Evaluation: Henry Pamos

Industrial Hy'gienist

Hazard Evaluation Serviceś Branch

Cincinnati, Ohio

Laboratory knalyses

: Vayne Sraill:rood

Division of Laboratory and Criteria Development Cincinnati, Ohio 